\title{
PENDIDIKAN MULTIKULTURAL DI PONDOK PESANTREN : Sebagai Strategi dalam Menumbuhkan Nilai Karakter
}

\author{
Heri Cahyono \\ Fakultas Agama Islam \\ Universitas Muhammadiyah Metro \\ E-mail: hericahyono808@gmail.com
}

\begin{abstract}
Indonesia as a country that has a wide range of cultural, ethnic, religious and economic backgrounds are different, plurality on the one hand provide the social power, but on the other hand is a challenge when it is not properly managed.Islamic boarding school as an educational institution that has a history of nation-building in Indonesia, ofcourse can be a forum in implementing multicultural education in the face of diversity. This paper describes the multicultural education at Islamic boarding school as a strategy to fostering thesocial soul in diversity.In its implementation does not distinguish from each other ranging from groups such as gender, ethnicity, race, culture, social background through treatment. Multicultural education has been stressed to the students in order to develop the potential and capacity to the maximum as it requires no special spaces in themselves and their environment.
\end{abstract}

Keyword: Education, Multicultural, Islamic Boarding School

\section{PENDAHULUAN}

Indonesia merupakan negara kepulauan, dan setiap masyarakat yang mendiaminya tentu memiliki ciri budaya tersendiri sehingga Indonesia sering kali disebut sebagai negara yang multi etnis, multi suku, multi agama, multi budaya bahkan sebagai negara yang cukup luas dengan memiliki luas wilayah 5.193.250 $\mathrm{km}^{2}$ (mencakup daratan dan lautan) sehingga pemerataan ekonomi dan pendidikan tidak merata, maka indonesia-pun disebut negara multi pendidikan serta multi ekonomi. Kemajemukan tersebut pada satu sisi merupakan kekuatan sosial dan keragaman yang indah apabila satu sama lain bersinergi dan saling bekerja sama untuk membangun bangsa dan negara. Namun, pada sisi lain kemajemukan tersebut apa bila tidak dapat dikelola dan dibina secara baik dan tepat maka akan menjadi sumber dan pemicu konflik maupun kekerasan yang dapat menggoyangkan sendi-sendi kehidupan berbangsa. Pristiwa di daerah asal penulis misalnya, wilayah Lampung-Mesuji merupakan contoh kekerasan dan konflik horizontal yang telah menguras energi dan kerugikan namun tidak hanya jiwa dan materi akan tetapi mengorbankan keharmonisan antar sesama masyarakat Indonesia.

Sedangkan dalam dunia pendidikan tidak sedikit sekolah yang melakukan dikotomi terhadap siswanya, bahkan sekolah-sekolah elitpun tanpa disadari telah 
melakukan dikotomi, seperti halnya memberikan fasilitas lebih terhadap siswa yang berasal dari kalangan elit dan memisahkan siswa yang berasal dari kalangan ekonomi menengah kebawah. Disamping itu dikotomipun dilakukan terhadap siswa yang memiliki tingkat kecerdasan/ kepandaian yang berbeda dengan diadakannya kelas unggulan atau yang pintar disatukan dengan yang pintar dan yang tidak pintar disendirikan. Padahal hakikat pendidikan, menurut John Dewey di dalam bukunya Experience and education", adalah a social process. Education is growth. Education is not preparation for life, education is life it self. Pendidikan adalah proses sosial. Pendidikan senantiasa bertumbuh. Pendidikan bukan persiapan untuk hidup, melainkan hidup itu sendiri ${ }^{1}$

Dari fonamena-fonamena tersebut diatas tentu memiliki implikasi bagi pembangunan bangsa dan karakter peserta didik. Oleh karena itu sudah barang tentu situasi yang berada di negeri ini harus dibenahi, mulai dari lembaga pendidikan hingga pada tatanan sosial. Baik lembaga pendidikan yang bersifat formal, non formal atau informal. Berbasis agama maupun lembaga pendidikan umum karena semua lembaga pendidikan memiliki tanggung jawab terhadap pembangunan bangsa.

Pondok pesantren harus mampu bertahan dan maju berkembang di tengah-tengah arus globalisasi tentunya memiliki esensi dasar yang tidak dapat terlepas darikarakteristik pesantren, yaitu lembaga pendidikan Islam yang berusaha menekankan akan pentinya pendidikan karakter Islami sebagai panduan dan pedoman hidup baik, ${ }^{2}$ namun saat ini masih ada terdapat pondok pesantren modern dimana di dalamnya tidak hanya mengajarkan ilmu-ilmu keagamaan semata namun mengajarkan ilmu pengetahuan dan teknologi.

Pondok Pesantren sebagai alternatif pendidikan multikulturalisme. Dimana pendidikan multikulturalisme secara formal diwujudkan dalam bentuk pengajaran materi keIndonesiaan/ kewarganegaraan yang telah dikurikulumkan. Sistem pengajaran di pondok modern yang didominasi bahasa asing (Arab dan Inggris) sebagai pengantar, tidak melunturkan semangat pendidikan multikulturalisme anak didik (santri). Karena materi ini ditempatkan sebagai materi primer dan harus diajarkan dengan medium bahasa Indonesia pula. Dalam bidang non formal, pesantren dengan kelebihan pendidikan intens 24 jamnya, memiliki banyak waktu untuk menyisipkan aneka pendidikan. Salah satunya multikulturalisme itu sendiri. Pola umum yang nyaris diberlakukan di berbagai pondok pesantren adalah sistem pendidikan multikultur yang menyatu dalam aturan dan disiplin pondok. Salah satunya dalam urusan penempatan pemondokan (asrama) santri.

Di Pondok Pesantren tidak diberlakukan penempatan permanen santri di sebuah asrama. Dalam arti, seluruh santri harus mengalami perpindahan

\footnotetext{
${ }^{1}$ https://diganovensa.wordpress.com/kata-mutiara-pendidikan, diakses tanggal 20 November 2016

${ }^{2}$ M. Ihsan Dacholfany, Pendidikan Tasawuf Di Pondok Modern Darussalam Gontor, Jurnal NIZHAM, Vol. 4, No. 2 Juli - Desember 2015, h.227
} 
sistematis ke asrama lain. Disamping itu santri tidak diperkenankan untuk bermewah-mewahan dalam bidang pakaian atau peralatan, dalam bidang makanan atau minuman seluruhnya tidak ada dikotomi meski sebagian dari mereka berasal dari kalangan ekonomi menengah keatas yang berasal dari berbagai wilayah dan daerah masing-masing. Disadari atau tidak hal ini dilakukan adalah sebagai awal dari pendidikan multikulturalisme guna menumbuhkan jiwa sosial terhadap keragaman.

\section{KAJIAN TEORI \\ Epistemologi Pendidikan}

Sebagai masyarakat awam, istilah pendidikan seringnya diidentikan dengan sekolah, guru mengajar di kelas, atau suatu pendidikan formal belaka. Secara akademik, istilah pendidikan berspekrum luas. Pendidikan adalah proses peradaban dan pemberadaban manusia. Pendidikan adalah aktivitas semua potensi dasar manusia melalui interaksi antara manusia dewasa dengan yang belum dewasa. Pendidikan adalah proses kemanusiaan dan pemanusiaan sejati.

Pendidikan juga disebut sebagai pemartabatan manusia menuju puncak optimal potensi kognitif, afektif dan psikomotorik yang dimilikinya. Pendidikan adalah proses membimbing, melatih, memandu manusia terhindar atau keluar dari kebodohan dan pembodohan. Pendidikan juga metamorfosis prilaku menuju kedewasaan sejati. Pendidikan juga dapat didefinisikan sebagai proses elevasi yang dilakukan secara nondiskriminasi, dinamis, dan intensif menuju kedewasaan individu, dimana proses dilakukan secara kontinue dengan sifat yang adaptif dan nirlimit atau tiada akhir. ${ }^{3}$

Istilah pendidikan berasal dari bahasa latin e-ducare atau educare yang berarti untuk memimpin atau memandu keluar, terbuka, membawa manusia menjadi mengemuka, proses menjadi terkemuka atau sebagai kegiatan terkemuka. ${ }^{4}$ selain itu istilah pendidikan juga dapat disebut sebagai "pedagogi" dan "pedagogik" pada khasanah pemikiran pendidikan kedua istilah tersebut memiliki peran yang saling memperkuat dimana pedagogi berarti pendidikan dan pedagogik ilmu pendidikan. ${ }^{5}$ Pedagogik atau ilmu pendidikan berarti ilmu yang menyelidika atau merenungkan tentang gejala-gejala perbuatan mendidik. Istilah ini berasal dari bahasa yunani pedagogia yang berarti pergaulan dengan anakanak dan istilah yang mashur pada waktu itu adalah pedagogos yang berarti seorang pelayan yang pekerjaannya mengantar dan menjemput anak-anak ke dan dari sekolah. Sedangkan dalam Garis Besar Haluan Negara pada tahun 1973 dikemukakan tentang pendidikan pada hakikatnya merupakan suatu usaha yang

\footnotetext{
3 Sudarwan Danim, Pengantar Pendidikan: Landasan, Teori, dan 234 Metafora Pendidikan, Bandung: Alfabeta, 2011, h.2

${ }^{4}$ Ibid., h. 3

${ }^{5}$ Choirul Mahfud, Pendidikan Multikultural, Yogyakarta: Pustaka Pelajar, 2014, h. 31
} 
disadari untuk mengembangkan keperibadian dan kemampuan manusia yang dilaksanakan didalam maupun diluar sekolah dan berlangsung seumur hidup. ${ }^{6}$

Selain itu definisi pendidikan juga dikemukakan oleh Ki Hadjar Dewantara dalam kongres taman siswa yang pertama pada 1930 ia menyebutkan, bahwa pendidikan pada umumnya berarti daya upaya untuk memajukan bertumbuhnya budi pekerti (kekuatan batin, karakter), pikiran intelek dan tubuh anak. dalam taman siswa tidak boleh dipisah-pisahkan bagian-bagian itu agar tidak dapat menjauhkan kesempurnaan hidup, kehidupan dan penghidupan anakanak yang kita didik selaras dengan duniannya. ${ }^{7}$ Orientasi pendidikan Islam di Indonesia masih mengalami perbedaan pendapat, terutama dalam menentukan pola, arah, dan capaian tertentu yang diinginkan ${ }^{8}$, sedangkan John Dewey dalam Nur Uhbiati mengemukakan bahwa pendidikan adalah proses pembentukan kecakapan-kecakapan fondamental secara intelektual dan emosional kearah alam dan sesama manusia. ${ }^{9}$ Terkait dengan pengertian-pengertian pendidikan diatas, maka akan timbul suatu pertannyaan pada diri kita, kapan pendidikan mulai muncul ?. maka pendidikan sebenarnya sudah ada sejak manusia pertama kali. Hanya saja cara dan sistem pendidikannya yang berbeda.

Pendidikan dewasa ini harus dilaksanakan dengan teratur dan sistematis agar dapat memberikan hasil yang sebaik-baiknya. Apalagi dunia pendidikan selain dihadapkan dengan perkembangan kemajuan teknologi dan tentu masyarakat yang semakin modern, budaya yang sangat beragam (multikultural). Dengan demikian pendidikan mau tidak mau harus merespon dan menyesuaikan dengan persinggungan budaya masyarakat sekitar. Maka persoalannya kemudian adalah bagaimana pendidikan berperan dalam merespon perubahan sosiokultural masyarakat dan mentransformasikan nilai-nilai budaya tersebut.

Dasar suatu pendidikan sebagai manusia yang mengaku akan Allah Tuhannya dan Islam sebagai agamanya, maka tentu yang menjadi dasar dari sebuah pendidikan adalah tidak lepas dari syari'at-syari'at yang telah ditentukan oleh Allah dan Rasul-Nya. Al-Qur'an dan Al-hadis dasar utama dalam tujuan suatu pendidikan yang ada di dunia ini bagi seorang muslim dengan menyatakan Islam Agama Allah yang diturunkan kepada para Rasul Allah sejak Nabi Adam sampai kepada Nabi Muhammad SAW yang didalamnya jelas berisi ajaran tentang tata cara hidup dan kehidupan umat manusia.

Apabila pada Nabi dan Rasul sebelum Muhammad SAW. Ajaran agama berwujud prinsip-prinsip yang isi dan pelaksanaannya sesuai dengan keadaan dan kebutuhan umat daerah tertentu, maka pada masa Nabi Muhammad SAW prinsip-prinsip pokok ajaran sesuai dengan keadaan dan kebutuhan umat secara

\footnotetext{
${ }^{6}$ Burhanudin Salam, Pengantar Pedagogik, Dasar-Dasar Ilmu Mendidik, Jakarta: Rineka Cipta, 1997, h. 4

${ }^{7}$ Choirul Mahfud, Pendidikan Multikultural,..... h. 33

${ }^{8}$ M. Ihsan Dacholfany, Reformasi Pendidikan Islam Dalam Menghadapi Era Globalisasi: Sebuah Tantangan Dan Harapan, Metro: Jurnal Akademika, 2015, h.179

${ }^{9}$ Abu Ahmadi dan Nur Uhbiati, Ilmu Pendidikan, Jakarta: Rineka Cipta, 2001, h. 69
} 
keseluruhan dan berlaku pada segala masa dan dimanapun berada. Maka sudah barang tentu ketika memang Islam telah disajikan sebagai suatu pedoman yang berlaku sepanjang masa maka dasar pendidikan yang ada dalam pembahasan ini tidak lepas dari Al-Qur'an dan Al-Hadist.

Selain itu terdapat pula yang disebut sebagai dasar pendidikan yang bersifat nasional, karena sebagai manusia yang bernegara maka tidak lepas pula ketika pendidikan yang akan dicapai tidak keluar dari dasar-dasar yang telah ditentukan dalam suatu dasar pendidikan nasional. adapun yang menjadi rumusan tentang pendidikan nasional dapat penulis kemukakan melalui pendapat Ki Hadjar Dewantara seorang tokoh pendidikan Nasional di Indonesia serta yang diangkat pemerintah sebagai Bapak Pendidikan, menyatakan sebagai berikut: "pendidikan nasional adalah pendidikan yang berlandaskan garis hidup dari bangsanya (cultureel nasional) dan ditunjukan untuk keperluan peri-kehidupan (maatschap pelijk) yang dapat mengangkat derajat negara dan rakyatnya agar dapat bekerja bersama-sama dengan lain-lain bangsa untuk kemualiaan segenap manusia diseluruh dunia". ${ }^{10}$

Pada dasarnya ada beberapa fungsi pendidikan sebagaimana disinggung diatas, maka setidaknya hal tersebut dapat dilihat dalam dua perspektif. ${ }^{11}$ Pertama. Secara mikro pendidikan berfungsi membantu perkembangan jasmani dan rohani peserta didik. Kedua. Secara makro pendidikan berfungsi sebagai pengembangan pribadi, pengembangan warganegara, pengembangan kebudayaan, dan pengembangan bangsa.

Selain berfungsi sebagaimana disebutkan diatas, pendidikan bisa juga berfungsi sebagai investasi jangka panjang. ${ }^{12}$ Menurut Nur Cholis dalam Mahfud dengan mengutip pendapat Thoshiko Kinosita dalam artikelnya "Pendidikan sebagai Investasi Jangka Panjang" sumber daya manusia Indonesia masih sangat lemah untuk mendukung perkembangan Industri dan Ekonomi. Penyebabnya pemerintah selama ini belum pernah menempatkan pendidikan sebagai prioritas terpenting. Masyarakat Indonesia mulai dari yang awam hingga politisi dan pejabat pemerintah, hanya berorientasi mengejar uang untuk memperkaya diri sendiri dan tidak pernah berpikir panjang, ${ }^{13}$ maka dalam hal ini fungsi pendidikan merujuk pada sumbangan pendidikan terhadap perkembangan dan pemeliharaan pendidikan pada tingkat sosial yang berbeda. Pada tingkat individual, pendidikan membantu siswa belajar cara belajar dan membantu guru cara mengajar. Orang yang berpendidikan diharapkan memiliki kesadaran untuk belajar sepanjang hayat (Life Long Learning), selalu merasa ketinggalan informasi, ilmu pengetahuan dan teknologi, sehingga terus terdorong untuk maju dan terus belajar.

\footnotetext{
${ }^{10}$ Abu Ahmadi dan Nur Uhbiati, Ilmu Pendidikan,... h. 190

${ }^{11}$ Ibid.

${ }^{12}$ Walter W. Mcmohan dan Terry G. Geske, Financing Education: Overcoming innefficience and Inequity, USA: University Of Illionis, 1982, h. 121

${ }^{13}$ Choirul Mahfud, Pendidikan,... h. 49
} 
Di masyarakat luas juga berlaku pendapat umum bahwa semakin berpendidikan, maka makin baik status sosial seseorang dan penghormatan masyarakat terhadap orang yang berpendidikan lebih baik daripada yang kurang berpendidikan. Orang yang berpendidikan diharapkan bisa menggunakan pemikiran-pemikiran yang berorientasi pada kepentingan jangka panjang. Orang yang berpendidikan diharapkan tidak memiliki kecenderungan orientasi materi apalagi untuk memperkaya diri sendiri.

\section{Konsep Pendidikan Multikultural}

Selain pengertian pluralis yang banyak diketahui orang bahwa dalam kehidupan sehari-hari di bidang akademisi, namun disini juga ada pengertian yang dianggap perlu diketahui yakni multikulturalisme. Akar kata dapat digunakan untuk memahami multikulturalisme adalah "kultur". Dalam catatan M. Ainul Yaqin dalam Ngainun Naim bahwa banyak ilmuwan dunia yang memberikan definisi kultur. Antara lain: Elizabeth B. Tailor (1832-1917) dan L.H. Morgan (1818-1881) yang memberikan kultur sebagai sebuah budaya yang universal bagi manusia dalam berbagai macam tingkatan yang dianut oleh seluruh masyarakat. Emile Durkhain (1858-1917) dan Marcel Maus (1872-1950) menjelaskan bahwa kultur adalah sekelompok masyarakat yang menganut sekumpulan simbol-simbol yang mengingat dalam sebuah masyarakat untuk diterapkan. ${ }^{14}$ Julian Steward (1902-1972) dam Leslie White (1900-1975) menjelaskan bahwa kultur adalah sebuah cara bagi manusia untuk beradaptasi dengan lingkungannya dan membuat hidupnya terjamin, ${ }^{15}$ walaupun pengertian kultur demikian beragam, tetapi ada beberapa titik kesamaan yang menemukan keragaman definisi yang ada tersebut. Salah satunya dapat dilakukan dengan mengidentifikasi karakteristiknya. Pertama. Kultur adalah suatu yang general dan spesifik sekaligus. General artinya setiap manusia di dunia mempunyai kultur, dan spesifiknya berarti setiap kultur adalah kelompok masyarakat bervariasi antara satu dengan yang lainnya tergantung kepada kelompok masyarakat yang mana kultur itu berada. Kedua. Kultur adalah suatu yang dipelajari. Seorang bayi atau anak kecil yang mudah meniru kebiasaan orang tuanya adalah contoh unik dari kapasitas kemampuan manusia dalam belajar. Ketiga. Kultur adalah sebuah simbol. Dalam hal ini simbol dapat berbentuk sesuatu yang verbal dan non verbal, dapat juga berbentuk bahasa khusus yang hanya dapat diartikan secara khusus pula, atau bahkan tidak dapat diartikan ataupun dijelaskan. Keempat. Kultur dapat membentuk dan melengkapi sesuatu yang alami. Secara alamiah, manusia harus makan dan mendapatkan energi, kemudian kultur mengajarkan pada manusia untuk makan makanan jenis apa,

14 Ngainun Naim dan Achmad Sauqi, Pendidikan Multikultural: Konsep dan Aplikasi, (Yogyakarta: Ar-Ruzz Media, 2008), hlm. 121. Lihat Juga. M. Ainul Yaqin, Pendidikan Multikultural, Cross-Cultural Understanding untuk Demokrasi dan Keadilan, Yogyakarta: Pilar Media, 2005, h. 27

${ }^{15}$ Ibid., h. 122 
kapan waktu makan dan bagaimana cara makan. Kultur juga dapat menyesuaikan diri kita dengan keadaan alam secara ilmiah dimana kita hidup. Kelima. Kultur adalah sesuatu yang dilakukan secara bersama-sama yang menjadi atribut bagi individu-individu sebagai anggota bagi kelompok masyarakat. Kultur secara alamiah ditransformasikan melalui masyarakat. Keenam. Kultur dapat diartiakan sebuah model. Artinya kultur bukan kumpulan adat istiadat dan kepercayaan yang tidak ada artinya sama sekali. Kultur adalah sesuatu yang disatukan dan sistem-sistem yang tersusun dengan jelas. Adat istiadat, institusi, kepercayaan, dan nilai-nilai adalah suatu yang saling berhubungan satu sama lain.

Ketika berbicara mengenai pengertian pendidikan multikultural, maka sesungguhnya pengertian tersebut masih belum terlalu jelas bahkan masih banyak pakar pendidikan yang memperdebatkan. Namun demikian, bukan berarti definisi pendidikan multikultural tidak ada atau tidak jelas. Sebetulnya sama dengan definisi pendidikan yang penuh penafsiran antara satu pakar dengan pakar lainnya didalam menguraikan makna pendidikan itu sendiri. Hal ini juga terjadi pada penafsiran tentang arti pendidikan multikultural.

Meminjam pendapatnya Tillar Pendidikan multikultural adalah merupakan suatu wacana yang lintas batas, karena terkait dengan masalahmasalah keadilan sosial (social justice), demokarasi dan hak asasi manusia. ${ }^{16}$ Azyumardi Azra dalam Imron mendefinisikan pendidikan multikultural sebagai pendidikan untuk atau tentang keragaman kebudayaan dalam merespon perubahan demografi dan kultur lingkungan masyarakat tertentu atau bahkan demi secara keseluruhan. ${ }^{17}$ Sedangkan Prudence Crandall mengemukakan bahwa pendidikan multikultural adalah pendidikan yang memperhatikan secara sungguh-sungguh terhadap latar belakang peserta didik baik dari aspek keragaman suku (etnis), ras, agama (aliran kepercayaam) dan budaya (kultur). Secara lebih singkat Andersen dan Custer (1994) mengatakan bahwa pendidikan multikultural adalah pedidikan mengenai keragaman budaya. ${ }^{18}$ Dan Musa Asy'ari juga menyatakan bahwa pendidikan multikultural adalah proses penanaman cara hidup menghormati, tulus, dan toleran terhadap keanekaragaman budaya yang hidup di tengah-tengah masyarakat plural. ${ }^{19}$

Dalam kontek pendidikan multikultural maka Tillar mengemukakan bahwa dalam program pendidikan multikultural, fokus tidak lagi diarahkan semata-mata kepada kelompok rasial, agama dan kultur domain atau mainstream. Fokus seperti ini pernah menjadi tekanan dalam pendidikan

16 H.A.R Tilaar, Kekusaan Dan Pendidikan Suatu Tinjauan Dan Persepektif Studi Kultural,Indonesia: Tera, 2003, h. 167

${ }^{17}$ Imron,Mashadi, Pendidikan Agama Islam Dalam Persepektif Multikulturalisme, Jakarta: Balai Litbang Agama, 2009, h. 48

${ }^{18}$ H.A Dardi Hasyim, Yudi Hartono. Pendidikan Multikultural di Sekolah. ( Surakarta: UPT penerbitan dan percetakan UNS, h . 28

${ }^{19} \mathrm{http}$ ://edukasi.kompasiana.com, pengertian-pendidikan-multikultural $435284 \mathrm{html}$ diakses pada 02 November 2016 
interkultural yang menekankan peningkatan pemahaman dan toleransi individuindividu yang berasal dari kelompok minoritas terhadap budaya mainstream yang domain, yang pada akhirnya menyebabkan orang-orang dari kelompok minoritas terintegrasi kedalam masyarakat mainstream. Pendidikan multikultural sebenarnya merupakan sikap "peduli" dan mau mengerti (difference) atau Politics of recognition (politik pengakuan dari kelompok orang-orang minoritas).

Dalam konteks itu pendidikan multikultural melihat masyarakat secara lebih luas. Berdasarkan pandangan dasar bahwa sikap "indiference" dan "nonrecognition" tidak hanya berakar pada ketimpangan struktur rasial, tetapi paradigma pendidikan multikultural mencakup subyek-subyek mengenai ketidak adilan, kemiskinan, penindasan dan keterbelakangan kelompokkelompok minoritas dalam berbagai bidang sosial, budaya, ekonomi, pendidikan dan lain sebagainya. Paradigma seperti ini akan mendorong tumbuhnya kajian-kajian tentang ethnic studies untuk kemudian menemukan tempatnya dalam kurikulum pendidikan sejak dari tingkat dasar hingga perguruan tinggi. Inti dari pembahasan subyek ini adalah untuk mencapai pemberdayaan (empowerment) bagi kelompok-kelompok minoritas dan disadventaged.

\section{Multikulturalisme membangun kesadaran etik kebangsaan}

Wacana multikulturalisme yang semakin menghangat akhir-akhir ini kurang terwadahi dalam ruang diskusi dalam masyarakat. Hal itu kurang menyebabkan masyarakat kurang begitu yakin dan sering kali memunculkan berbagai kontroversi dalam merumuskan seputar paham multikulturalisme. Apalagi masih saja terus berlangsung penolakan dari sebagian umat islam yang berimplikasi terhadap rapuhnya tata nilai kehidupan dalam tataran praktis. $^{20}$

Stigma yang berkembang saat ini menyatakan bahwa pendidikan islam merupakan pendidikan yang berbasiskan agama. Seperti halnya civil education, pendidikan Islam sering dikesankan sebagai sistem rekayasa sosial pendidikan yang bercorak dogmatis, doktriner, monolitik, dan tidak berwawasan multikultural. Agama disatu sisi membentuk tipe-tipe kultur masyarakat. Bahkan, membentuk kultur yang begitu khas sehingga secara sosiologis sering muncul dalam bentuknya yang sangat eksklusif. Agama manapun kemudian menampilkan corak kultur pemeluknya yang khas dan eksklusif pula.

Padahal, Islam melalui lembaga pendidikan keagamaan seperti pesantren, dalam perkembangan selanjutnya banyak mendapatkan perhatian dari berbagai kalangan. Tidak hanya dari instusi-instusi Islam (insider), tetapi juga dari kalangan non muslim (outsider). Hal ini memberikan nilai lebih bagi

${ }^{20}$ Sulalah, Pendidikan Multikultural: Didaktika Nilai-Nilai Universalitas Kebangsaan, Malang: UIN Maliki Press, 2012, h. 4 
Islam untuk memberi penegasan eksistensi kelembagaan serta berperan positif dalam kehidupan berbangsa. Selain itu perhatian positif akan menghidupkan suasana dialogis di antara komunitas yang banyak terlupakan pada masa belakangan ini.

Posisi Islam dalam membangan dialog dengan masyarakat sedemikian strategis. Ini menjadikan Islam memiliki peran besar dalam rangka membangun kerjasama yang saling menguntungkan dan menghargai antara elemen masyarakat dari berbagai karakter belakangannya. Melalui lembaga pendidikan keagamaan seperti pesantren, ajaran Islam disemaikan sekaligus dibumikan sejalan dengan nilai-nilai multikultural tanpa memandang latar belakang agama, etnis maupun status sosial. Sebuah toleransi yang dibangun atas dasar kesadaran bersama akan heterogenitas budaya demi terwujudnya masyarakat yang harmonis dan seimbang. Memang proses pelaksanaan pendidikan multikultural dalam Islam tidak semua berjalan lancar. Ada kendala-kendala yang menjadikan prinsip-prinsip multikultural tidak berjalan secara maksimal. Atas dasar ini seudah sepatutnya lembaga pendidikan keagamaan dimanapun agar merasa terpanggil untuk menjadikan pendidikan bermuatan multikultural sebagai agenda yang sangat signifikan dalam memberi ruang bagi eksistensi, pengakuan, dan penghormatan kepada agamaagama lain.

Posisi lembaga pendidikan keagamaan sangat strategis, diupayakan untuk dapat membangun kerjasama yang saling menguntungkan dan menghargai antara elemen masyarakat dari berbagai karakter. Salah satu yang telah dilakukan sebagai wujud nyata integrasi dari hal itu adalah membangun kedasaran multikulturalisme dilingkungan pendidikan. ${ }^{21}$ memang pengembangan multikultural masih belum dilakukan secara maksimal. Implementasi pendidikan multikultural masih bersifat insidentil, dalam forum-forum ilmiah belum memiliki agenda yang bersifat priodik, serta tidak masuk dalam bagian kurikulum formal. Bahkan tak jarang pimpinan lembaga pendidikan keagamaan masih belum memberikan apresiasi yang signifikan dalam pelaksanaan pendidikan multikultural dengan mengoptimalkan pembangunan moral religius seperti yang tertuang dalam visi misi lembaga. Untuk itu "keteladanan" yang diperankan para akademis dilembaga pendidikan keagamaan dalam berucap, bersikap, dan berperilaku menjadi alternatif dan metode yang paling strategis dalam mengimplementasikan pendidikan multikultural. Sesungguhnya tata cara dan perilaku para elit mempunyai pengaruh dalam ruang lingkup budaya masyarakat yang multikultural. Mereka juga dituntut tunduk pada norma dan nilai yang berkembang di masyarakat.

Ketika konsep multikultural mejadi suatu pemahaman bersama, maka tatacara prilaku para aktor dalam suatu seting budaya tertentu tidak akan bersi

${ }^{21}$ Ibid, h. 6 
kukuh pada budayanya masing-masing. Bahkan secara konsensus dapat diakui ketika peneguhan dan penegasan identitas diri atau kelompok keagamaan, akan terbangun fondasi yang kokoh dan tidak tergoyangkan dengan cara apapun. Bahkan jika perlu dengan segala cara yang dianggap wajar dan masih dalam batas-batas yang dapat dipertanggung jawabkan secara sosial. ${ }^{22}$

Terlebih pesona Indonesia yang terdiri dari sekitar 350 bahasa, 600 suku bangsa dengan identitas masing-masing, ${ }^{23}$ serta 6 agama yang masuk kategori besar yaitu: Islam, Kristen, Hindu, Budha, Katholik dan Kong $\mathrm{Hu} \mathrm{Cu}$. Seyogyanya mampu mendorong diskursus mendalam para tokoh agama mengenai wacana multikultural. Pada kenyataanya peran masyarakat yang tinggal dan hidup pada bentangan pulau dari sabang sampai marauke belum secara maksimal mengapresiasi wacana ini. ${ }^{24}$

Realitas kultur dan perkembangan kondisi sosial politik dan budaya bangsa Indonesia dalam pusaran waktu terus menggeliat. Apalagi era reformasi yang penuh dengan gejolak sosial politik dalam berbagai level masyarakat menempatkan pendidikan multikultural pada posisi yang semakin urgen, relevan bahkan sangat dibutuhkan. Kenyataan sosial itu pun dipahami secara berbeda-beda oleh masyarakat. Setiap komunitas keagamaan menyerap bentuk tafsiran tentangan kenyataan sosial secara terbatas. Ini dikarenakan setiap individu berbeda-beda dalam dimensi penyerapan aspek tertentu saja. Tidak setiap individu dapat menjaga keseimbangan dalam penyerapan informasi. Kenyataan yang diterima individu dari lembaga sosial, membutuhkan cara penjelasan dan pembenaran atas kekuasaan yang sedang dipegang dan diperaktikan. Pelembagaan pandangan atau pengetahuan oleh masyarakat akhirnya memperoleh generalisasi yang paling tinggi. Hal tersebut terbangun dalam dunia yang dikenal sebagai pandangan hidup atau ideologi.

Hal yang mendasar dan harus menjadi perhatian adalah bahwa pendidikan yang seragam dan tidak menghargai terhadap pluralis justru tidak membawa implikasi negatif. Ketika pendidikan Islam tidak hanya sekedar diarahkan untuk mengembangkan manusia yang beriman dan bertaqwa, tetapi juga bagaimana berusaha mengembangkan manusia untuk menjadi imam atau

${ }^{22}$ Pertanggungjawaban secara sosial akan terwujud manakala hakikat peneguhan jati diri tidak menimbulkan ekses bagi kelompok lain yaitu berubah dan berkembang menjadi suatu yang tidak wajar, tidak nyaman dan mengarah kepada suatu yang lebih destruktuf dan membahayakan kehidupan bersama umat manusia. Gejala semacam ini tergambar dari pemahaman keagamaan yang bercorak literal-skriptual. Lihat. Sulalah, Pendidikan Multikultural: didaktika nilai-nilai universalitas kebangsaan, Malang: UIN Maliki Press, 2012, h. 7

${ }^{23}$ Data tersebut berdasarkan sensus tahun 2005 dengan jumlah total 33 Provinsi, dan 32 macam tradisi. Lihat. Satyo Adi, ATLAS (Surabaya: Bintang Usaha Jaya, 2005. Bisa dilihat pula pada Hamarni Zada, Agama dan Etnis: tantangan pluralisme di Indonesia, nilai-nilai pluralisme dalam islam, Jakarta: Nuansa Fatayat NU-Ford Foundation, 2006, h. 184

${ }^{24}$ Keanekaragaman agama sejalan dengan konsepsi manusia terhadap realitas, dimana konsepsi mereka terhadapnya tidak didasarkan kepada pengetahuan tetapi kepada keyakinan adanya "otoritas" yang berbeda-beda antara agama satu dengan agama lainnya. Lihat, Sulalah, Pendidikan Multikultural: didaktika nilai-nilai universalitas kebangsaan, Malang: UIN Maliki Press, 2012, h. 7 
pemimpin bagi orang yang beriman dan bertaqwa. Untuk memenuhi standar ideal in, perlu pengembangan pendidikan agama Islam yang berorientasi pada tujuan, obyek dan subyek didik serta metodologi pengajaran yang digunakan. ${ }^{25}$

Adapun tujuan pendidikan pluralis-multikulturalis menurut Clive Back, adalah:

a)Teaching "etnic" student about their own ethnic culture, including prophap some "britage language" instruction and b) teaching all student about various traditional cultures, at home and abroad. While such studies can pursued in a variety of ways, what is usually missing is systematic treatment of fundamental issues of culture and etnicity. c) promoting acceptance of etnic diversity in society; d) showing that people of differents religions races, national background and so and are equel worth. e) fostering full acceptance and equitable treatment of the etnic sub-cultures associated with different religious, races, national background etc. In one's own country and in other parts of the word; and f) helping student to work toward more adequate cultural forms, for themselves and for society. ${ }^{26}$

Untuk mewujudkan pendidikan yang bercorak pluralis dan multikulturalis semacam ini, dalam proses keyakinannya, setiap komunitas pendidikan perlu memerhatikan konsep unity and diversity. Selain itu juga harus disertai dengan sikap yang tidak saja mengandaikan suatu mekanisme berpikir terhadap agama yang tidak monointerpretable, atau menanamkan kesadaran bahwa keragaman dalam hidup sebagai suatu kenyataan yang harus dihadapi dan disikapi dengan penuh kearifan, tetapi juga memerlukan kesadaran moralitas dan kebajikan. Tentu saja penanaman konsep seperti ini dilakukan dengan tidak mempengaruhi kemurnian masing-masing agama yang diyakini kebenarannya oleh anak didik. Ini yang harus memperoleh penegasan agar tidak terjadi kesalah pahaman. ${ }^{27}$

\section{Pendidikan multikultural di Pesantren}

Potret pesantren dapat dilihat berbagai segi sistem pendidikan di pesantren secara menyeluruh, yang meliputi: materi pelajaran dan metode pengajaran, prinsip-prinsip pendidikan, sarana dan tujuan pendidikan di

${ }^{25}$ Muhaimin, Wacana Pengembangan Pendidikan Islam, Yogyakarta: Pustaka Pelajar, 2003, h. 143

26 Ngainun Naim dan Achmad Sauqi, Pendidikan ..., h. 53. Lihat juga. Syamsul Mu'arif, Pendidikan Pluralis di Indonesia, Yogyakarta: Logung Pustaka, 2005, h. 93-94

${ }^{27}$ Ibid., h. 53 
pesantren, kehidupan kiai dan santri serta hubungan keduanya. Masingmasing dapat diuraikan sebagai berikut. ${ }^{28}$

a. Materi pelajaran dan metode pengajaran

Pada dasarnya pesantren hanya mengajarkan ilmu dengan sumber kajian atau mata pelajaran kitab-kitab yang ditulis atau berbahasa Arab. Sumber-sumber tersebut mencakup al-Qur'an beserta tajwid dan tafsirnya, aqa'id dan ilmu kalam, fiqih dan ushul fiqih, al-hadits dan musthalahah al-hadits, bahasa Arab dengan seperangkat ilmu alatnya. Sumber-sumber kajian ini bisa disebut sebagai kitab-kitab kuning. Adapun metode yang lazim digunakan dalam pendidikan pesantren adalah wetonan, sorogan, dan hafalan. ${ }^{29}$

b. Jenjang pendidikan

Jenjang pendidikan di pesantren tidak dibatasi seperti dalam lembagalembaga pendidikan yang memakai sistem klasikal. Umumnya, kenaikan tingkat seseorang santri didasarkan kepada isi mata pelajaran tertentu yang ditandai dengan tamat dan bergantinya kitab yang dipelajarinya. Apabila seseorang santri telah menguasai satu kitab dan beberapa kitab dan lulus ujian, yang diuji oleh kiainya, maka dengan ini akan berpindah kekitab lain yang lebih tinggi tingkatannya. Jelasnya, penjenjangan pendidikan pesantren tidak berdasarkan usia tetapi berdasarkan pada penguasaan kitab-kitab yang telah ditetapkan dari paling rendah sampai paling tinggi. ${ }^{30}$

c. Prinsip-prinsip pendidikan di pesantren

Nurcholish Majid dalam Shulthon menjelaskan setidaknya ada duabelas prinsip yang melekat pada pendidikan di pesantren yaitu: teosentrik, ikhlas dalam pengabdian, kearifan, kesederhanaan, kolektifitas, mengatur kegiatan bersama, kemandirian, kebebasan terpemimpin, tempat menuntut ilmu dan mengabdi, mengamalkan ajaran agama, belajar di pesantren untuk mencari ijazah dan kepatuhan terhadap kiai.

Merujuk kepada uraian terdahulu, maka dapat diidentifikasi ciri-ciri pesantren, sebagai berikut: ${ }^{31}$

a. Adanya hubungan yang akrab antara santri dengan kiainya. Kiai sangat memperhatikan santrinya. Hal ini dimungkinkan karena mereka sama-sama tinggal dalam satu kompleks dan sering bertemu baik disaat belajar maupun dalam pergaulan sehari-hari. Bahkan sebagai santri diminta menjadi asisten kiai.

28 Shulthon Masyhud dan Moh. Khusnurdilo, Manajemen Pondok Pesantren, Jakarta: Diva Pustaka, 2005, h. 88

${ }^{29}$ Ibid., h. 89

${ }^{30}$ Ibid., h. 89

${ }^{31}$ Ibid., h. 93 
b. Kepatuhan santri kepada kiai. Para santri menganggap bahwa menantang kiai, selain tidak sopan juga dilarang agama, bahkan tidak memperoleh berkah karena durhaka kepadanya sebagai guru.

c. Hidup hemat dan sederhana benar-benar diwujudkan dalam lingkungan pesantren. Hidup mewah hampir tidak didapatkan di pesantren. Bahkan sedikit santri yang hidupnya terlalu sederhana atau terlalu hemat sehingga kurang memperhatikan gizi.

d. Kemandirian amat terasa di pesantren, para santri mencuci pakaian sendiri, membersihkan kamar tidur sendiri, dan memasak sendiri.

e. Jiwa tolong menolong dan jiwa persaudaraan sangat mewarnai pergaulan di pesantren. Ini disebabkan selain kehidupan yang merata di kalangan santri, juga karena meraka harus mengerjakan pekerjaanpekerjaan yang sama, seperti shalat berjamaah, membersihkan masjid dan ruang belajar bersama-sama.

f. Disiplin sangat dianjurkan. Untuk menjaga kedisiplinan ini pesantren biasanya memberikan sanksi-sanksi edukatif.

g. Keperihatinan untuk mencapai tujuan mulia. Hal ini sebagai akibat kebiasaan puasa sunah, dzikir dan i'tikaf, shalat tahajud, dan bentukbentuk riyadoh lainnya atau menauladani kiainya yang menonjolkan sikap zuhud.

h. Pembiasaan ijazah pencantuman nama dalam daftar rantai pengalihan pengetahuan yang diberikan kepada santri-santri yang berprestasi.

Ciri-criri lembaga pendidikan agama Islam yang secara khusus disebut sebagai pondok pesantren sebagai pesantren yang masih memiliki bentuk yang masih murni (tradisional). Adapun penampilan pesantren yang saat ini semakin beragam merupakan akibat dinamika kemajuan zaman yang turut mendorong terjadinya suatu perubahan. Adapun penampilan pesantren yang saat ini semakin beragam merupakan akibat dinamika kemajuan zaman yang turut mendorong terjadinya suatu perubahan yang nyata secara kontinue, sehingga lembaga tersebut melakukan berbagai adopsi dan adaptasi sedemikian rupa sehingga tidak bertentangan dengan kemajuan zaman sehingga dapat diterima oleh masyarakat yang semakin heterogen. Artinya secara jelas lembaga pendidikan pesantren melakukan perubahan namun tidak mengurangi eksistensinya sebagai lembaga pendidikan yang bersifat multikultural dalam berbagai ruang.

Implementasi pendidikan multikultural di pesantren

Wacana multikulturisme dalam agama Islam diperkenalkan melalui konsep rahmatan lil'alamin (QS 21:107). Di dalam konsep tersebut, agama Islam menunjukkan bahwasanya manusia mempunyai kedudukan yang sama secara lahiriyah. Jadi, tidak ada istilah diskriminasi yang dilandaskan pada pembedaan jenis kelamin, suku, ras, dan budaya. 
Dengan kata lain, setiap manusia mempunyai hak dan kewajiban yang sama dalam setiap aspek kehidupan, yang dalam hal ini pendidikan merupakan salah satunya. Dalam dunia pendidikan, paradigma multikulturalisme digaungkan sebagai salah satu upaya dalam membangun suatu hubungan yang erat, kuat serta mendalam antara keberagaman etnik, ras, agama, budaya dan status masyarakat. Hal ini sebagai langkah awal dalam membangun pendidikan yang merata bagi setiap orang dan menghilangkan pola pikir bahwa pendidikan hanya teruntuk kalangan tertentu saja. ${ }^{32}$

Lembaga pendidikan yang berbasis keagamaan, khususnya pondok pesantren merupakan institusi yang tepat dalam memberdayakan pendidikan yang bersifat multikultural. Tidak dapat dipungkiri, bahwasannya pondok pesantren tidak hanya menekankan pada pendidikan agama semata. Akan tetapi, juga memberikan nilai plus dalam pembentukan akhlak dan pengembangan potensi anak di dalam setiap pergaulan yang dilandasi sifat kekeluargaan dan saling tolong menolong.

Pesantren yang menjadi basis keagamaan sekaligus pendidikan dari puluhan ribu santri. Disinilah para santri yang kelak akan menjadi penerus bangsa ini dididik sampai mereka menyadari peran dan fungsinya dalam menjalankan eksistensinya sebagai warga negara, tokoh keagamaan atau pejabat publik, oleh karena itu, penanaman nilai-nilai (values) menghargai perbedaan, saling bersikap arif (wise) dalam memandang perbedaan, bahkan saling tolong menolong menjadi bagian fundamen dalam menanamkan benih-benih pendidikan pesantren berbasis multikulturalitas. ${ }^{33}$

Basis sistem pendidikan di Pondok Pesantren adalah kemajemukan sehingga terejawantah sikap saling mengayomi, menghargai dan menghormati diantara sesama santri. Sikap demikian, harus juga dilihat bagaimana hubungannya dengan semua penghuni masyarakat di sekitarnya, bagaimana mereka berkomunikasi dan membaur dengan non muslim sehingga tetap terpelihara kebhinekaannya itu.

Kehidupan yang berlangsung dalam pondok pesantren telah diatur sedemikian rupa sehingga seorang santri yang belajar di dalamnya akan merasakan bahwa dirinya sedang berada diantara keluarga. Ia diajarkan untuk bergaul dan berkreasi bersama teman-temannya yang mempunyai latar belakang berbeda-beda.Segala macam perselisihan dan persaingan yang timbul dari perbedaan struktur budaya, akan mendorong santri untuk lebih memahami arti persatuan dan kebersamaan. Pesantren melihat perbedaan bukanlah jurang yang akan pemisah. Tapi, ia adalah jembatan untuk mendongkrak prestasi dan bakat santri. Dengan berbagai macam perbedaan, mereka dituntut untuk bekerja sama antara satu dengan yang

\footnotetext{
${ }^{32}$ http://alfianorrahman.blogspot., diakses tanggal 23-10-2016

${ }^{33}$ Abdullah Aly, Pendidikan Islam Multikultural di Pesantren: Telaah terhadap Kurikulum Pondok Pesantren Modern Islam As Salaam Surakarta, Yogyakarta: Pustaka Pelajar, 2011, h. 43
} 
lainnya dan menekan segala ego yang mungkin timbul dalam pergaulan mereka menjadi sebuah motivasi untuk bergerak maju dan menghasilkan kreasi dan inovasi yang baru. ${ }^{34}$

Dengan kita memperhatikan terhadap aspek nilai, sistem, dan materi, maka pondok pesantren sebagai lembaga pendidikan Islam yang tertua di Indonesia memainkan peranan yang sangat vital dalam mempersiapkan masyarakat madani melalui modernisasi sistem pendidikan pesantren. Dengan modernisasi pesantren diharapkan mampu melahirkan Sumber Daya Manusia (SDM) yang memiliki kepribadian holistik (insan kamil). Yaitu kepribadian yang memiliki keseimbangan antara lima aspek: spiritual, intelektual, sosial, emosional, dan fisik. Insan kamil tidaklah terbentuk begitu saja secara instant, namun perlu proses yang cukup panjang. Proses tersebut adalah merupakan transfer of knowledge and inculcation of moral values from one generation to another generation.

Pola umum yang nyaris diberlakukan di berbagai pondok modern adalah sistem pendidikan multikultur yang menyatu dalam aturan dan disiplin pondok, sebagai berikut: ${ }^{35}$

a. Di Pondok modern, tidak diberlakukan penempatan permanen santri di sebuah asrama. Hal ini ditujukan untuk memberikan variasi kehidupan bagi para santri, juga menuntun mereka memperluas pergaulan, dan membuka wawasan mereka terhadap aneka tradisi dan budaya santrisantri lainnya.

b. Diberlakukannya aturan mengikat yang melarang santri berbicara menggunakan bahasa daerah. Selain bahasa utama Arab dan Inggris, ketika masuk lingkungan pondok santri hanya dibolehkan berbicara Bahasa Indonesia dalam beberapa kesempatan dan kepentingan.

c. Keberagaman pemikiran dan ijtihad diajarkan kepada santri tanpa pemaksaan, atau mengajarkan mereka untuk memaksakan ide. Sikap toleransi terhadap perbedaan pendapat sangat diunggulkan sistem pendidikan pondok pesantren.

d. Dengan sistem Mu'allimin yang didukung intensitas pendidikan 24 jam, masa pendidikan luar kelas di pondok pesantren cenderung lebih banyak dibandingkan waktu formal pembelajaran di dalam kelas.

e. Mengajarkan pewawasan santri akan keragaman keyakinan, serta menerapkan pewawasan aneka kultur dan budaya para santrinya. Hal ini ditujukan untuk membangun kesadaran toleransi keragaman keyakinan yang akan para santri temui disaat hidup bermasyarakat kelak, dan

\footnotetext{
34 http://alfianoorrahman.blogspot.com/2014/10/pondok-pesantren-sebagai-basis.html, diakses tanggal 23 November 2016

${ }^{35} \mathrm{http}: / /$ vivixtopz.wordpress.com/artikel-islam/ -pendidikan multikulturalisme/ diakses tanggal 26 November 2016
} 
pewawasan kebhinekaan budaya dalam lingkungan yang akan mereka huni.

\section{SIMPULAN}

Pendidikan multikultural merupakan suatu disiplin ilmu yang sedang menjadi pembicaraan yang cukup hangat dalam kalangan akademis, sebagai suatu konsep pendidikan yang lahir di Indonesia pada Abad 21 ini menunjukan bahwa cukup memiliki wacana pendidikan di masyarakat yang memiliki sifat progresif mendatang.

Pendidikan multikultural di lembaga pendidikan Islam atau yang sering dikenal dengan pondok pesantren tradisional talah lebih dahulu menerapkan sistem pendidikan yang memiliki konsep multikultural baik dari segi mata pelajaran yang dipelajari, sistem lingkungan yang dibangun, mapun status sosial yang dimiliki masing-masing santri. Dalam implementasinya seluruh santri tanpa membedakan satu sama lain mulai dari kelompok seperti gender, etnik, ras, budaya, strata sosial, bahkan agama. Pendidikan multikultural telah menekankan kepada siswa agar dapat mengembangkan potensi dan kapasitasnya secara maksimal dengan tanpa melakukan ruang-ruang spesial dalam diri dan lingkungannya.

Keragaman memang sangat diperlukan dalam kehidupan sosial di masyarakat majemuk, terutama di Indonesia. Pesantren sebagai basis pendidikan yang ideal harus mengusung nilai kebhinekaan dan tidak monoton bahkan tertutup. Sistem pendidikan multikultur yang menyatu dalam aturan dan disiplin pondok, yaitu tidak diberlakukan penempatan permanen santri di sebuah asrama, dilarangnya santri berbicara menggunakan bahasa daerah selain bahasa utama Arab dan Inggris di lingkungan pondok, diajarkannya keberagaman pemikiran dan ijtihad kepada santri tanpa pemaksaan, sikap bertoleransi terhadap perbedaan pendapat dan keragaman keyakinan, serta mempunyai wawasan aneka kultur dan budaya.

\section{DAFTAR PUSTAKA}

Abdullah Aly, Pendidikan Islam Multikultural di Pesantren: Telaah terhadap Kurikulum Pondok Pesantren Modern Islam As-Salaam Surakarta, Yogyakarta: Pustaka Pelajar, 2011

Abu Ahmadi dan Nur Uhbiati, Ilmu Pendidikan, Jakarta: Rineka Cipta, 2001.

Burhanudin Salam, Pengantar Pedagogik, Dasar-Dasar Ilmu Mendidik, Jakarta: Rineka Cipta, 1997 
Choirul Mahfud, Pendidikan Multikultural, Yogyakarta: Pustaka Pelajar, 2014

H.A Dardi Hasyim, Yudi Hartono. Pendidikan Multikultural di Sekolah. Surakarta: UPT penerbitan dan percetakan UNS

H.A.R Tilaar, Kekusaan Dan Pendidikan Suatu Tinjauan Dan Persepektif Studi Kultural. Indonesia: Tera, 2003

Hamarni Zada, Agama dan Etnis: tantangan pluralisme di Indonesia, nilainilai pluralisme dalam Islam, Jakarta: Nuansa Fatayat NU-Ford Foundation, 2006

Imron,Mashadi, Pendidikan Agama Islam Dalam Persepektif Multikulturalisme, Jakarta: Balai Litbang Agama, 2009

M. Ihsan Dacholfany, Reformasi pendidikan Islam Dalam Menghadapi Era Globalisasi: Sebuah Tantangan Dan Harapan, STAIN Metro: Jurnal Akademika, Lampung: Jurnal Akademika, 2015

M. Ihsan Dacholfany, Pendidikan Tasawuf Di Pondok Modern Darussalam Gontor, Jurnal NIZHAM, Vol. 4, No. 2 Juli - Desember 2015

Mu'arif, Pendidikan Pluralis di Indonesia, Yogyakarta: Logung Pustaka, 2005

Muhaimin, Wacana Pengembangan Pendidikan Islam, Yogyakarta: Pustaka Pelajar, 2003

Ngainun Naim dan Achmad Sauqi, Pendidikan Multikultural: Konsep dan Aplikasi, Yogyakarta: Ar-Ruzz Media, 2008

Satyo Adi, ATLAS Surabaya: Bintang Usaha Jaya, 2005

Shulthon Masyhud dan Moh. Khusnurdilo, Manajemen Pondok Pesantren, Jakarta: Diva Pustaka, 2005

Sudarwan Danim, Pengantar Pendidikan: Landasan, Teori, dan 234 Metafora Pendidikan, Bandung: Alfabeta, 2011 
Sulalah, Pendidikan Multikultural: didaktika nilai-nilai universalitas kebangsaan, Malang: UIN Maliki Press, 2012

Undang-undang Sisdiknas Tahun 2003 dan Lihat. Choirul Mahfud, Pendidikan Multikultural, Yogyakarta: Pustaka Pelajar, 2014

Walter W. Mcmohan dan Terry G. Geske, Financing Education: Overcoming innefficience and Inequity, USA: University Of Illionis, 1982

Yaqin, Pendidikan Multikultural, Cross-Cultural Understanding untuk Demokrasi dan Keadilan, Yogyakarta: Pilar Media, 2005

http://alfianoorrahman.blogspot.com/2014/10/pondok-pesantren-sebagaibasis.html

http://alfianorrahman.blogspot.com/2014/10/pondok-pesantren-sebagaibaisi.html

http://edukasi.kompasiana.com/2012/01/31/pengertian-pendidikanmultikultural-435284.html

http://vivixtopz.wordpress.com/artikel-islam/pesantren-modern-danpendidikan multikulturalisme/ 